\title{
Decision Support System of The People's Business Credit Method Using Analytical Hierarchy Process at Bank Syariah Mandiri Kc. Lubuk Pakam
}

\author{
Dhini Andika', Penda Sudarto Hasugian² \\ ${ }^{1.2}$ Informatics Engineering Study Program, STMIK Pelita Nusantara, Jl. Iskandar Muda No. 1 \\ Medan, North Sumatra, Indonesia 20154 \\ E-mail:dini.andika@yahoo.com,penda.hasugian@gmail.com ,
}

\begin{abstract}
Decision support system (DSS) system that can help someone in making decisions that are accurate and right on target. Many problems can be solved by using the SPK. One of them is Determining the eligibility of customers receiving the People's Business Credit (KUR). There are Several methods that can be used in building a DSS, Including Analytical Hierarchy Process (AHP). The application of the AHP method to the decision support system of people's business credit through a number of processes of data transformation starts from Determining the priority scale of each criterion, to getting the final grade and ranking. In Determining the eligibility of KUR recipient customers, there are Several criteria that are the basis for decision making, Including Credit Status, Productive Business, Business Conditions, Collateral and Collectibility.
\end{abstract}

Keywords : SPK AHP, KUR

\section{Introduction}

Rapid technological developments influence the workings of personal and organization, especially in banking, technology can help the development of banking dikarenkan with technology can be an accurate information as a tool to monitor the activities going on in banking include providing small loans, information technology will be very helpful in running a business in the banking (Ade Hendini 2016)Many cases can be solved by using the SPK, among other analytical hierarchy process (AHP). AHP is a method most widely used methods in solving problems that are multiple criteria, such as the eligibility determination SPK KUR recipient customers. This study using AHP in determining eligibility. In determining who is eligible to receive small loans. the process of determining the criteria, business credit is still not accurate, decision support systems (DSS) to the selection criteria for determining the eligibility of prospective customers in providing small loans. (KUR).

\section{Theory}

\subsection{Understanding Systems}

Systemis a collection of interrelated elements that are responsible for processing the input (inputs) to produce output (output). (Dr.kusrini, M.Kom, 2017: 11). While the system can be simply defined as a group of elements that are interconnected or integrated interact to form a union. a common goal to achieve common tertentu.Konsep target system is a group of interrelated components receive input and produce output in an orderly transformation process. system, consisting of a system that emphasizesthe procedures and systems that emphasize elements. The systems approach that emphasizes the procedure defined by Jerry Fitz Gerald. According to him, the system as a network that consists of procedures that are interconnected, then gathered together to perform or complete the activities and achieve a certain goal. Robert G. Murdick, a system composed of interconnected elements. Integrated with the same purpose to achieve the expected goals. So based on a systems approach can be deduced that the system elements or procedures that are prepared and integrated with the common goal to achieve a specific goal (Nurul Alifah Rahmawati 2018).

\section{a. Types of Systems}

1) The system is a collection of components that each have an element of the relationship between each other open.

2) System is a collection of systems that are not influenced by outsiders because of its access closed.

3) The system is an alloy composed of several elements / elements that are connected into a single unit so as to facilitate the flow of information and material / energy to achieve a certain goal. 
4) System is a network of procedures interconnected, gathered together to be able to make or complete a specific target.

b. characteristics System

1) Systems that have components of the system boundary, siste environment, connecting the input, processing and output targets.

2) Openness is an area that limits between a system with other systems or with the outside environment. This system limits allows a system viewed as a whole.

3) Outside the system environment is anything beyond the limits of the system that affect system operation.

\section{Research methods}

\subsection{Framework Research}

Research is a series of steps carried out planned and systematic way in order to get pemecehan problem or get answers and specific questions.

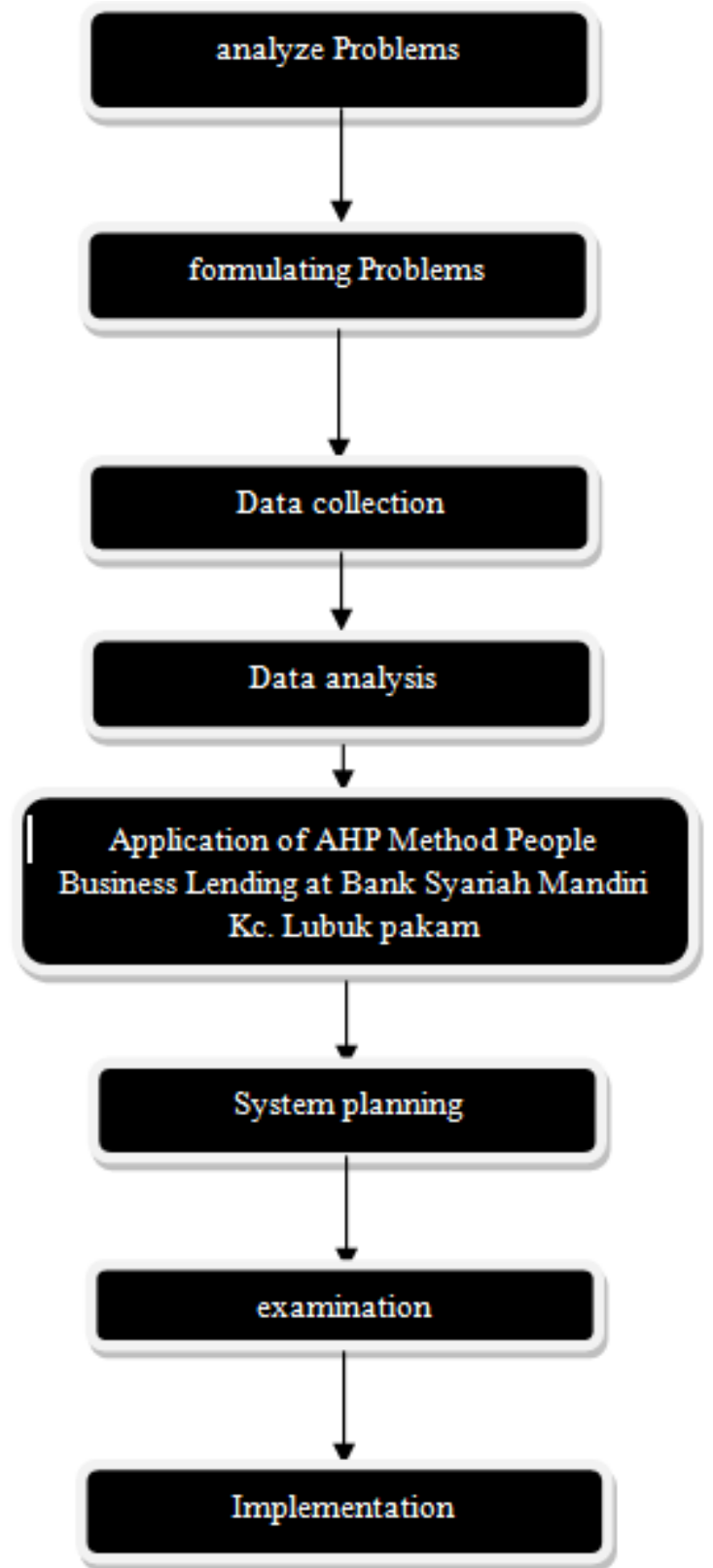

Fig 1. Framework 
a. Analyze Problems

Analysis of the problem is a problem which will be discussed in this peneliian and data that will be used in the system to be used in any system that is in-kriteia determining the criteria that will be used.

b. formulate the problem

At this stage the formulation obtained from this study are: how to solve the problem in the selection of the customer to accept the people's business credit (KUR).

c. Data collection

As for the data collected in the study is as follows:

a) Literature review

A literature study by collecting and finding and studying a variety of reading materials and the necessary data are sourced from books and journals in particular of decision support system of microcredit (KUR) and the method of Analytical Hierarchy Process (AHP)

b) Observation (observation)

These observations were made by directly observing the work so as to obtain an overview of the selection of the best employees in the company.

c) Data analysis

From the data analysis we can conclude several criteriarequired in the system that is :

Discipline, ethics, responsibility, work, team skills (skills to enter). It is for the grouping to the data that will allow authors pass analysis.

d) Application of the method ahp providing small loans on a standalone Islamic bank KC.lubuk Pakam Implementation of algorithms with AHP in providing small loans to customers are the steps necessary logic to problem solving and programming. The algorithm used to mengalisa and explain the relationship between the order and the procedures that will be pursued.

The steps in conducting AHP analysis is as follows:

a) Develop a chart of the problems faced, there are 4 . The criteria to be analyzed which is more dominant weights including credit status, Productive business, business conditions and Kolektibitas Guarantee.

b) Assessment of supplier selection criteria-kritea expressed numerically with a scale of 1 through 9.3angka-figures show a final result of two two criteria for assessing the comparison criteria to assess the intensity of the interest rate comparison a criterion to other criteria.

c) Perancamgan system In this study, there are several steps in designing a system include: shape the look of the design are made according to the needs of the study area.

d) examination

This test is to determine the weaknesses that may occur in inputting the code of the program and to ensure that input is bounded deliver results in accordance with the needs.

e) Implementation

An implementation or application of which will be based on the design of which has been compiled. Implementation should be done with a design that has been made so that the results achieved as expected.

\section{Analysis And Design}

\subsection{Analysis}

Results of analysis of this research is to load and researchers who have carried out the bank Syariah Mandiri Kc. Lubukpakam, where researchers collecting the data required in the design of the application of methods Analyitycal Hierarchy Process (AHP) to determine the criteria of business credit recipient on a standalone Islamic bank kc.lubuk Pakam data obtained through interviews with the Head Branch of Islamic banks and the independent Lubukpakam staff, case studies and literature that the author lakukkan gradually to obtain the appropriate data.

\section{a. Analysis Method of AHP}

Here is a candidate criteria needed for decision-making, based on the provisions stipulated by Bank Syariah Mandiri Kc. Lubukpakam, there are several criteria that are set as follows: Credit Status, Produkktif Enterprises, Security and Collectible then created a level of importance criteria based on the intensity of interest in each in each of the following criteria. Table 1 intensity kepemtingan / prioritize the criteria.

\section{Table 1}

Criteria

\begin{tabular}{llll}
\hline No. Criteria & $\begin{array}{l}\text { The intensity } \\
\text { of Interests }\end{array}$ & Information & comparison Criteria \\
\hline
\end{tabular}


Journal of Computer Networks, Architecture and High Performance Computing

e-ISSN 2655-9102, Volume 2, No. 1, January 2020, pp 120-123

\begin{tabular}{|c|c|c|c|c|}
\hline No. & Criteria & $\begin{array}{l}\text { The intensity } \\
\text { of Interests }\end{array}$ & Information & comparison Criteria \\
\hline 1 & Credit Status & 1 & $\begin{array}{l}\text { The second element is } \\
\text { equally important }\end{array}$ & $\begin{array}{l}\text { Credit status is as important to Effort } \\
\text { Productive }\end{array}$ \\
\hline 2 & $\begin{array}{l}\text { productive } \\
\text { Enterprises }\end{array}$ & 1 & $\begin{array}{l}\text { The second element is } \\
\text { equally important }\end{array}$ & $\begin{array}{l}\text { Enterprises equally productive pentingna } \\
\text { with Business Conditions }\end{array}$ \\
\hline 3 & $\begin{array}{l}\text { Business } \\
\text { conditions }\end{array}$ & 3 & $\begin{array}{l}\text { Elements that one a little } \\
\text { more important, than the } \\
\text { other elements. }\end{array}$ & $\begin{array}{l}\text { Business conditions a little more important } \\
\text { than the Status of Credit, Business } \\
\text { Productive, Guarantees, Collectible }\end{array}$ \\
\hline 4 & security & 5 & $\begin{array}{l}\text { The second element is more } \\
\text { important than any other } \\
\text { element }\end{array}$ & $\begin{array}{l}\text { Guarantees, Collectability more important } \\
\text { than others. }\end{array}$ \\
\hline 5 & Collectable & 5 & $\begin{array}{l}\text { The second element is more } \\
\text { important than any other } \\
\text { element }\end{array}$ & $\begin{array}{l}\text { Collectability Security is more important } \\
\text { than others. }\end{array}$ \\
\hline
\end{tabular}

\section{Conclusion}

The conclusion drawn in supporting a support system is using ahp.bisa used as a guideline for providing small loans (KUR) Through some data transformation process begins of scaling criteria, until the final value and perangkingan. With the decision support system is used to determine who is eligible for business loans directly from the Bank Syariah Mandiri to the value of the final result tertinngi customers.

\section{Reference}

[1] Asep Muhidin 2017."Perancangan Sistem Informasi Produk Hasil Repair Pada PT.JCV Kenwood Elektronik Indonesia"

[2] Bosker Sinaga 2014. "Sistem Pendukung Keputusan Siswa Berprestasi Menggunakan Metode Analytic Hierarchy Process (AHP) Pada SMK Singosari Delitua." Jurnal Mantik Penusa.

[3] Cahyo dimas K 2016. "Sistem Pendukung Keputusan Pemberian Kredit MenggunakanD3"

[4] Dian Permatasari 2018. "Sistem Pendukung Keputusan Pemberian Kredit Pada Koperasi Wanita Salimah Payah Kumbuh Berbasis Syariah Menggunakan Metode Analytic Hierarchy Proses (AHP)"Jurnal Sistem Informasi dan Manajemen Informatika.

[5] Eka Riani 2014. "Sis tem Pendukung Keputusan Pemberian Kredit Usaha Pada PT Bank Jateng Semarang"

[6] Fitri Nuraeni 2015. "Sistem Pendukung Keputusan Pemberian Kredit Usaha Rakyat (KUR) Menggunakan Metode Weighted Product"

[7] Gortap Lumbantoruan, Emma Rosinta Br Simamata 2018. "Sistem Pendukung Keputusan Penentuan Wali Kelas Berdasarkan Prestasi Guru Dengan Metode Simple Additive Weighting" Jurnal Informatika dan Informatika

[8] Heri Nurdiyanto, Heryanita Meilia 2016. " Sistem Pendukung Keputusan Penentuan Prioritas Pengembangan Induus Kecil Dan Menengah Di Lampung Tengah Menggunakan Analitical Hierarchy Proses (AHP)"

[9] Indah Tiara 2018. "Sistem Pendukung Keputusan Penilaian Kinerja Karyawan Keputusan Penilaian Kinerja Karyawan Pada Kementrian Sosial Republik Indonesia Menggunakan Metode AHP"

[10] Jijon Raphita Sagala, Guntur Syahputra 2019. “Sistem Pendukung Keputusan Dalam Penentuan Jabatan Kapolres Di Jajaran Kepolisian Daerah Sumatera Utara (Polda Sumut) Dengan Metode Simple Additive Weight (SAW)" Jurnal Mantik Penusa.

[11] Kamalia Safitri, Fince Tinus Waruwu,Mesran 2017. “Sistem Pendukung Keputusan Pemilihan Karyawan Berprestasi Dengan Menggunakan Metode Analytical Hierarchy Process (AHP)"

[12] Leni Natalia Zulita 2013. "Sistem Pendukung Keputusan Menggunakan Metode SAW Untuk Penilaian Dosen Beprestasi (Studi Kasus Di Universitas Dehasen Bengkulu" Jurnal Media Infotama.

[13] Murni Marbun, Bosker Sinaga 2017. "Sistem Pendukung Keputusan Penilaian Hasil Belajar Mahasiswa Dengan Metode Topsis Di STMIK Pelita Nusantara Medan"Jurnal Mantik Penusa.

[14] Nelly Astuti Hasibuan 2016. "Sistem Pendukung Keputusan Dalam Pemberian Pinjaman Kredit Usaha Rakyat Menggunakan Metode AHP" Jurnal Riset Komputer.

[15] Okta Veza 2017. "Sistem Pendukung Keputusan Dalam Prosedur Penggolahan Qta Prakualifikasi Tender Pada Dinas Prasarana Jalan, Tata Ruang Dan Permukiman Propinsi Kepulauan Riau"

[16] Penda Sudarto Hasugian, Harvei Desmon Hutahaen, Hengki Tamando Sihotang 2017. "Sistem Pendukunlgeputusan Penentuan Guru Wali Kelas Pada SMP Negeri 19 Medan Dengan Menggunakan Metode Simple Additive Weighting" Jurnal Informatika Pelita Nusantara. 